\title{
PATRONAT WOJSKOWY JANA SOBIESKIEGO W LATACH 1667-1696. ROLA, ZNACZENIE, POSTULATY BADAWCZE
}

\author{
Zbigniew Hundert
}

http://orcid.org/0000-0002-5088-2465

Zamek Królewski w Warszawie - Muzeum

\section{ABSTRACT \\ JOHN III SOBIESKI'S MILITARY PATRONAGE IN 1667-1696. THE ROLE, IMPORTANCE AND RESEARCH POSTULATES}

The article describes the mechanism of military patronage of John III Sobieski in the period of 1667-1696. It provides a synthesis of the current state of research, focusing mostly on the time when Sobieski held the hetman office (highest ranking military officer) and when he established a system of military patronage which gave him full control over the Crown (Polish) army and allowed him to use it in his political actions. Another objective of the article is to identify areas for further research, especially regarding the post-1683 period.

Keywords: military patronage, clientelism in the army, John III Sobieski.

Słowa kluczowe: patronat wojskowy, klientela wojskowa, Jan III Sobieski.

Wojsko w drugiej połowie XVII wieku zaczęło odgrywać w Rzeczypospolitej nieporównywalnie większą rolę niż w latach ubiegłych, co wiązało się z większym zapotrzebowaniem na żołnierza, wynikającym z licznych konfliktów, w które uwikłane było państwo polsko-litewskie. Wyższa kadra dowódcza proweniencji magnackiej tworzyła równocześnie elity państwowe, sprawowała bowiem urzędy senatorskie i dygnitarskie i miała w związku z tym poważny wpływ na bieżącą politykę. Zdecydowanie wzrosła również polityczna rola hetmanów, których kompetencje kształtowały się na zasadzie faktów dokonanych, a to ułatwiało dysponentom buław kształtowanie prerogatyw tak, by dostosować je do aktualnych potrzeb politycznych. Decydenci wywodzący się ze środowiska wojskowego swoje zaplecze polityczne tworzyli przede wszystkim w armii - tym samym angażowali oni własnych podkomendnych do działalności na swoją korzyść na arenie publicznej. Dzięki ludziom 
objętym patronatem hetmanów i wyższej kadry dowódczej, reprezentującej warstwę senatorsko-dygnitarską, zdobyli wpływ na instytucje ustrojowe państwa, takie jak sejm, sejmiki, trybunały czy komisje skarbowe i hibernowe. Najlepiej wpływ patronatu wojskowego na sytuację wewnętrzną w Rzeczypospolitej - czemu w Koronie drogę utorowały wydarzenia związane z konfederacjami lat 1661-1663 i rokoszem Lubomirskiego - jest dostrzegalny w czasach Sobieskiego. Wybrany na króla w 1674 roku Jan III wywodził się ze środowiska wojskowego i w przemożnym stopniu swoją najsilniejszą pozycję $\mathrm{w}$ państwie $\mathrm{w}$ przeddzień własnej elekcji zawdzięczał armii koronnej ${ }^{1}$. Żeby mieć możliwość oddziaływania na żołnierza koronnego, Sobieski, jeszcze jako hetman i marszałek, musiał wypracować odpowiednie mechanizmy, które oparte były w dużej mierze na systemie patronatu wojskowego i rozpatrywanego czasem oddzielnie zjawiska wojskowej klienteli².

W ostatnich latach polscy naukowcy coraz silniej akcentują w swych badaniach rolę wojskowego patronatu i klienteli, aczkolwiek jedyną większą pracę poświęconą wyłącznie tym zagadnieniom przygotowała Urszula Augustyniak ${ }^{3}$. Wielu ustaleń i wniosków zawartych w tej rozprawie nie sposób jednak odnieść do czasów Sobieskiego w armii koronnej, Augustyniak zajmowała się bowiem armią litewską z pierwszej połowy XVII wieku, za buławy Krzysztofa II Radziwiłła. Wojsko Wielkiego Księstwa nie miało w tym okresie charakteru armii stałej, ponadto siły zbrojne Rzeczypospolitej nie przeszły jeszcze wówczas istotnych zmian, które wynikały z konieczności prowadzenia długotrwałych wojen na kilku teatrach operacyjnych (wpisuje się to w tzw. rewolucję militarną̧ ), co skutkowało o wiele mniejszym zasięgiem oddziaływań patronatu niż później. W wielu opracowaniach dotyczących wojskowości polskiej czasów Sobieskiego sporo kwestii zostało już dostatecznie dobrze wyjaśnionych. Odnosi się to przede wszystkim do „przedkrólewskiego” okresu

1 Z. Hundert, Między buława a tronem. Wojsko koronne $w$ walce stronnictwa malkontentów z ugrupowaniem dworskim w latach 1669-1673, Oświęcim 2014, passim (syntetycznie w zakończeniu, s. 347-353).

2 W historiografii anglojęzycznej pojęcia patronatu i klientelizmu są synonimami. Niektórzy polscy badacze, zwłaszcza ci zajmujący się obszarem Wielkiego Księstwa Litewskiego, oddzielają te dwa terminy, by podkreślić różnice między protegowanymi magnata - uczestniczącymi w życiu publicznym (klientela) a ludźmi zobowiązanymi do służby i posłuszeństwa $\mathrm{z}$ tytułu użytkowania ziemi w dobrach swego pryncypała (patronat); więcej na ten temat: K. Żoj dź, „Stronnictwo Zygmunta III Wazy w Wielkim Księstwie Litewskim w latach 1603-1621”, mps pracy doktorskiej napisanej w Instytucie Historycznym Uniwersytetu Warszawskiego pod kierunkiem prof. dra hab. M. Nagielskiego, Warszawa 2018, s. 33-34, tam obszerne omówienie stanu badań na temat klientelizmu i patronatu, w tym wojskowego, w Europie wczesnonowożytnej; zob. też K. Żojdź, Klientela hetmana wielkiego litewskiego Jana Karola Chodkiewicza i jej losy po śmierci patrona, „Przegląd Historyczny” 2015, t. 106, z. 1, s. 31-68.

3 U. Augustyniak, $W$ stużbie hetmana i Rzeczypospolitej. Klientela wojskowa Krzysztofa Radziwilta (1585-1640), Warszawa 2004. Stan badań w Polsce na temat patronatu wojskowego przedstawił ostatnio: K. Żojdź, Patronat wojskowy i klientela hetmańska Jana Karola Chodkiewicza. Zarys problematyki [w:] Studia nad staropolska sztuka wojenna, t. IV, red. Z. Hundert, K. Żojdź, J.J. Sowa, Oświęcim 2015, s. 69-70.

4 Stała siła zbrojna istniała na Litwie de facto od 1648 r., ale de iure dopiero od $1717 \mathrm{r}$.

5 Zob. jedną z ważniejszych prac w tej kwestii: The Military Revolution Debate: Readings on the Military Transformation of Early Modern Europe, ed. C.J. Rogers, Boulder 1995. 
życia Sobieskiego, aczkolwiek coraz więcej wiemy też o roli patronatu wojskowego w trakcie panowania Jana III. Niewątpliwie omawiane zjawisko w dobie Sobieskiego, a przede wszystkim zjawisko samego patronatu hetmana i późniejszego króla, należy podzielić na trzy okresy: czasy hetmańskie Sobieskiego, czyli lata 1666-1674 (choć bardziej właściwą dolną cezurą czasową winien być rok $1667^{\circ}$ ); pierwsze dziesięciolecie rządów Jana III, gdy dokonywało się przeistoczenie patronatu z zależności wódz-podkomendni w zależność król-poddani; oraz okres „powiedeński” (1683/1684-1696), gdy wpływy monarchy w wojsku koronnym zostały ograniczone przez działalność hetmana wielkiego Stanisława Jana Jabłonowskiego?.

W momencie gdy marszałek wielki koronny Jan Sobieski uzyskał w maju 1666 roku buławę polną, nie miał w wojsku koronnym większego zaplecza, które mogłoby umocnić jego pozycję. Niemniej w latach 60 . XVII wieku nawiązał w ramach stronnictwa dworskiego Jana Kazimierza kontakty z wyższymi oficerami armii koronnej, którzy w przyszłości stali się jego głównym oparciem w strukturach sił zbrojnych Korony. Byli to między innymi wojewoda ruski Stanisław Jan Jabłonowski, strażnik koronny Mikołaj Hieronim Sieniawski, kasztelan sądecki Aleksander Ludwik Niezabitowski, wojewoda kijowski Michał Stanisławski, pisarz polny koronny Jakub Potocki, podstoli sandomierski i oberszter gwardii JKM Marcjan Ścibor Chełmski oraz kilku wyższych oficerów piechoty w zaciągu niemieckim. Nie najsilniejsza pozycja Sobieskiego w wojsku wynikała z tego, że sprawował on urzędy, które zostały zabrane Jerzemu Sebastianowi Lubomirskiemu, a o których przywrócenie domagał się sam zainteresowany, między innymi za pośrednictwem dość silnej klienteli wojskowej. Ponadto Sobieski nie był należycie doceniany - ani przez samego monarchę, ani przez hetmana wielkiego Stanisława „Rewerę” Potockiego. Wyraźna zmiana nastąpiła w tej materii w 1667 roku, a pierwszymi istotnymi wydarzeniami, które się do tego przyczyniły, była niemal równoczesna śmierć Lubomirskiego, co dezaktualizowało sprawę przywrócenia rokoszanina do urzędów, oraz hetmana „Rewery”. W związku z tym, że nie przyznano buław koronnych na sejmie wiosennym 1667 roku, Sobieski pozostał jedynym hetmanem koronnym, dlatego to właśnie na niego spadło zadanie wykonania ustawodawstwa sejmowego w postaci redukcji wojska do komputu pokojowego i zadośćuczynienia żądaniom finansowym żołnierzy, nieopłaconym za okres służby $1663-1667^{8}$.

Sobieski w tym wszystkim odnalazł się bardzo umiejętnie. Najpierw zdołał pozyskać klientelę wojskową Lubomirskiego, która w przyszłości okazała się jednym $\mathrm{z}$ podstawowych filarów jego wpływów w armii, następnie dokonał redukcji wojska tak, że w kompucie znalazło się wiele jednostek i formacji, których szlachta nie chciała utrzymać, a których patroni należeli do jego politycznych przyjaciół i zarazem zwolenników koncepcji dworu zakładającej osadzenie na polskim tronie Kondeusza. Przychylność wojska zyskał także przez sprawne prace na trybunale skarbowym, który realnie wypłacił żołnierzom wiele zaległości, i wreszcie przez sukces

6 Więcej zob. Z. Hundert, Między buławą a tronem..., s. 34-83.

7 Zob. M. Wagner, Stanisław Jabłonowski (1634-1702). Polityk i dowódca, t. I, Siedlce 1997, s. $228-229$.

8 Z. Hundert, Między buława a tronem..., s. 34-83. 
kampanii podhajeckiej jesienią 1667 roku. Sukces ten nie tylko zacieśnił relacje z podkomendnymi, ale też przekonał wielu możnych, że Sobieski będzie odgrywać wielką rolę w państwie i warto z nim współpracować, przekonał również do hetmana społeczeństwo szlacheckie, które pojęło, że jest właściwą osobą na właściwym miejscu9. Dzięki temu bez przeszkód uzyskał buławę wielką koronną, stając się pierwszą osobą w historii Polski, która skupiła w jednym ręku tak ważne urzędy, jak marszałka wielkiego i hetmana wielkiego ${ }^{10}$.

Mechanizmy wypracowane w 1667 roku zapewniły Sobieskiemu możliwość wpływania za pomocą wojska na sytuację w państwie aż do roku 1674, gdy dzięki swoim podkomendnym przybyłym na pole elekcyjne uzyskał koronę $e^{11}$. Hetman wielki opierał się na swojej klienteli wojskowej, w tym na żołnierzach uzależnionych od niego ekonomicznie (choćby przez dzierżawy w jego dobrach), oraz na patronacie swoich najbliższych współpracowników i zarazem wpływowych magnatów, którzy od 1667 roku przez długie lata byli blisko związani z marszałkiem i przyszłym królem - chodzi przede wszystkim o wspominanych wcześniej Jabłonowskiego, Sieniawskiego, wojewodę kijowskiego Andrzeja Potockiego czy po 1670 roku kawalera maltańskiego Hieronima Augustyna Lubomirskiego. Sobieski opierał się także na oficerach zaliczanych do patronatu swoich „cywilnych” współpracowników, takich jak wojewoda krakowski Aleksander Michał Lubomirski. Tu można wskazać choćby strażnika koronnego Stefana Bidzińskiego czy porucznika husarskiego Władysława Wilczkowskiego. W patronacie wojskowym Sobieskiego istotną rolę odgrywały też szeroko rozumiane więzi rodzinne, stąd promocja w wojsku szwagra Ludwika Maligny d'Arquien, siostrzeńca ks. Aleksandra Janusza Zasławskiego-Ostrogskiego, kuzynów Jana Karola i Mikołaja Daniłowiczów czy męża dalekiej kuzynki Elżbiety z Sobieskich - Władysława Denhoffa, starosty starogardzkiego ${ }^{12}$. Celem tych działań było stworzenie oddanego sobie profesjonalnego zaplecza, niezbędnego do prowadzenia działań wojennych, jak również do wpływania na bieżącą sytuację wewnętrzną w Rzeczypospolitej ${ }^{13}$. Zaangażowanie wojska koronnego i jego skuteczne wykorzystanie w działalności opozycyjnej przeciw Michałowi Korybutowi w latach 1669-1673 nie podlega przecież dyskusji.

\section{Ibidem.}

10 Zob. F. Dupont, Pamiętniki historyi życia i czynów Jana III Sobieskiego, thum. B. Spieralska, oprac. D. Milewski, Warszawa 2011, s. 54; Z. Hundert, Między butawa a tronem..., s. 128; K. Wiśniewski, Jan Sobieski jako marszałek wielki koronny [w:] Marszatek i hetman koronny Jan Sobieski, red. D. Milewski, Warszawa 2014, s. 19-36.

11 K. Wiśniewski, op. cit., s. 31-34; Z. Hundert, Wojsko koronne a elekcja 1674 roku [w:] Wokót wolnych elekcji w państwie polsko-litewskim XVI-XVIII wieku. O znaczeniu idei wyboru-między prawami a obowiązami, red. M. Markiewicz, D. Rolnik, F. Wolański, Katowice 2016, s. 308-332.

12 Z. Hundert, Między buławą a tronem..., s. 153-193; idem, Władysławów Denhoffów dwóch, „Przegląd Historyczny” 2016, t. 107, z. 2, s. 303-310.

13 Tę ważną tezę sformułował jeszcze Marek Wagner; M. Wagner, Towarzysze broni Jana Sobieskiego [w:] Jan Sobieski - wódz i polityk (1629-1696). W trzechsetna rocznice śmierci, red. J. Wojtasik, Prace Instytutu Historii Wyższej Szkoły Rolniczo-Pedagogicznej w Siedlcach, nr 23, Siedlce 1997, s. 58; por. Z. Hundert, Między buławq a tronem..., s. 169. 
Patronat wojskowy Sobieskiego, ukształtowany w czasach hetmańskich, miał również swoje przełożenie na oddziaływanie na społeczności lokalne. Sobieski był posesjonatem przede wszystkim w województwie ruskim, podobnie jak jego polityczni przyjaciele - Jabłonowski, Sieniawski, Andrzej i Jakub (zm. w 1671 r.) Potoccy - i jak pokazują prowadzone badania, najwięcej kadry oficerskiej czy towarzyskiej w jednostkach zaciągu polskiego rekrutowało się z obszarów wpływów politycznych wspomnianych decydentów (jednocześnie pokrywały się z geografią ich dóbr). Dzięki temu opozycja wobec Michała Korybuta potrafiła zdobyć sobie wpływ na zaciąg wojsk powiatowych sejmików wiszeńskiego i halickiego województwa ruskiego w 1671 roku. Ówczesna aukcja wojska była prowadzona za pomocą samorządów, a nie w sposób centralny, by ograniczyć wpływ opozycyjnych oficerów na nowe zaciągi. Możliwość politycznego oddziaływania na sejmiki wiszeński czy halicki poskutkowała tym, że zaciągi województwa ruskiego w latach 1672 i 1673 znacznie zasłużyły się Sobieskiemu militarnie i politycznie, wbrew intencjom króla Michała i jego doradców ${ }^{14}$. Oprócz województwa ruskiego miejscem działania klienteli wojskowej Sobieskiego i jego współpracowników było województwo krakowskie, gdzie wyróżniali się Chełmscy i ludzie zaliczani do patronatu Lubomirskich - w tym sami Hieronim Augustyn i jego brat Aleksander, pułkownicy wojska koronnego ${ }^{15}$.

Patronat wojskowy hetmana Sobieskiego umożliwił pozostanie większości wojska koronnego w strefie wpływów opozycji, a także zneutralizował działania ks. Dymitra Wiśniowieckiego, hetmana polnego, który po pogodzeniu się z Sobieskim na przełomie lat 1670 i 1671 przestał politycznie występować przeciw swojemu starszemu koledze. Niesiony poczuciem solidarności zawodowej wsparł nawet Sobieskiego podczas konfederacji szczebrzeszyńskiej z listopada 1672 roku, faktycznie wymierzonej w jego królewskiego krewniaka, Michała. Należy też pamiętać, że oddziaływanie na postawy wojska przez patronat Sobieskiego i wyższych oficerów (który zdecydowanie przyćmił patronat króla i jego współpracowników, takich jak Szczęsny Potocki, Stanisław Koniecpolski czy Stefan Stanisław Czarniecki) było możliwe dzięki prawnym aspektom (umiejętnie zresztą rozgrywanym) postanowień komisji lwowskiej z 1667 roku (której przewodniczył Sobieski), obowiązującym w praktyce

14 Szeroko na ten temat: Z. Hundert, Zaciężne wojsko powiatowe sejmiku wiszeńskiego województwa ruskiego $w$ latach 1671-1673 oraz jego rola $w$ działaniach wojskowych i politycznych Jana Sobieskiego, „Przegląd Historyczny” 2017, t. 108, z. 4, s. 641-671.

15 Więcej zob. M. Sokalski, Między królewskim majestatem a szlachecka wolnościa. Postawy polityczne szlachty matopolskiej w czasach Michała Korybuta Wiśniowieckiego, Kraków 2002, s. 15-47. O roli Lubomirskich w systemie patronatu hetmańskiego Sobieskiego zob. też Z. Hundert, Działalność wojskowa i polityczna Hieronima Augustyna Lubomirskiego w latach 1669-1673 - glosa do biografii [w:] Hortus bellicus. Studia z dziejów wojskowości nowożytnej. Prace ofiarowane profesorowi Mirosławowi Nagielskiemu, red. K. Bobiatyński [et al.], Biblioteka Epoki Nowożytnej, t. 5, Warszawa 2017, s. 391, 393-395. Sam hetman Sobieski pisał 20 stycznia 1674 r. ze Stryja do wojewody krakowskiego Aleksandra Michała Lubomirskiego, ,[...] że w województwie krakowskim zda się, że mamy najwięcej przyjaciół [...]”, Pisma do wieku i spraw Jana Sobieskiego, oprac. F. Kluczycki, t. 1, cz. 2, Kraków 1881, s. 1402. Słowa te znakomicie oddają wpływy jego środowiska politycznego, opartego w znacznej części na kadrach wojska koronnego, w tym „górnym” województwie; zob. ibidem. 
do 30 kwietnia 1673 roku $^{16}$. Gdy po pogodzeniu się króla z opozycją wojsko koronne zostało na potrzeby komputu wojennego rozbudowane niemal trzykrotnie, Sobieski i jego stronnicy znacznie powiększyli liczbę wojsk bezpośrednio od siebie zależnych. Sam hetmański pułk jazdy był dwukrotnie większy niż królewski (co za Jana Kazimierza się nie zdarzało), ponadto Sobieski wprowadził do wojska swoich „cywilnych” sojuszników - wojewodę kaliskiego Jana Opalińskiego oraz kasztelana poznańskiego Krzysztofa Grzymułtowskiego, którzy w kampanii chocimskiej stali na czele własnych pułków jazdy ${ }^{17}$. Obaj zresztą byli związani z Wielkopolską, obszarem, na którym Sobieski nie cieszył się popularnością. Pytanie zatem, czy nie odegrali oni pewnej roli w pozyskaniu chorążego poznańskiego Władysława Skoraszewskiego, osoby, która jeszcze w 1672 roku była aktywna po stronie wrogiej konfederacji szczebrzeszyńskiej kierowanej przez Sobieskiego, jako pułkownik zaciągów powiatowych sejmiku średzkiego ${ }^{18}$. Skoraszewski wyróżnił się w samej bitwie chocimskiej, a już niebawem reprezentował hetmana wielkiego jako dwukrotny szef delegacji wojskowej wysłanej na konwokację i elekcję w 1674 roku. Zadaniem deputacji wojskowych było wszak zapewnienie Sobieskiemu wpływu na elekcję i w konsekwencji powołania go na tron ${ }^{19}$. Patronat hetmański zatem się rozszerzał, zarówno o osoby, jak i o możliwość wpływania na kolejne obszary w Koronie. Sam Skoraszewski, gdy Sobieski był już Janem III, stawał na straży interesów królewskich, czym dowiódł nieformalnych związków z monarchą ${ }^{20}$.

Przeistoczenie dotychczasowych form patronatu Sobieskiego w naturalny sposób musiało się dokonać po wstąpieniu hetmana na tron. Generalnie patronat wojskowy samego monarchy oraz jego sojuszników, którzy w pierwszym dziesięcioleciu rządów nadal pozostawali blisko związani z królem, stanowił w zasadzie najważniejszą metodę wpływania Jana III na wojsko koronne. Król utracił bowiem systemowe uprawnienia, którymi dysponował jako hetman (np. sądownictwo wojskowe, kierowanie na leża, rozdział hiberny), ale dysponował za to możliwością prowadzenia polityki kadrowej za pomocą listów przypowiednich. Dużą rolę odgrywała tu współpraca $\mathrm{z}$ hetmanem polnym Jabłonowskim przeciw hetmanowi wielkiemu Dymitrowi Wiśniowieckiemu, który nie podzielał, przede wszystkim w latach 1677-1679, politycznych koncepcji króla, dlatego zajmowane przez niego stanowisko stwarzało zagrożenie dla wpływów Jana III w wojsku ${ }^{21}$. Podobną metodę monarcha chciał zastosować w 1683 roku, gdy po awansie Jabłonowskiego na wakującą buławę większą

16 Z. Hundert, Między butawa a tronem..., passim (syntetycznie w zakończeniu, s. 347-353).

17 Ibidem, s. 189; idem, Pozycja Jana III w wojsku koronnym w latach 1674-1683. Utrzymanie czy też utrata wplywów wypracowanych w czasie sprawowania godności hetmańskiej? [w:] Król Jan III Sobieski i Rzeczpospolita w latach 1674-1683, red. D. Milew ski, Warszawa 2016, s. 121-125, 141.

18 Idem, Powiatowe choragwie kozackie (pancerne) województw poznańskiego i kaliskiego w latach 1671-1673 [w:] Do szarży marsz, marsz... Studia z dziejów kawalerii, red. A. Smoliński, t. 6, Toruń 2015, s. 85-86, 92-93.

19 Idem, Wojsko koronne a elekcja 1674..., s. 315-318, 323-325.

20 A. Kamieński, Skoraszewski Władysław [w:] Polski słownik biograficzny, t. XXXVIII, Warszawa-Kraków 1997, s. 256-259; K. Matwij ow ski, Pierwsze sejmy z czasów Jana III Sobieskiego, Wrocław 1976, s. 100; Z. Hundert, Pozycja Jana III..., s. 143-144.

21 Z. Hundert, Pozycja Jana III..., s. 121-151. 
(Wiśniowiecki zmarł w 1682 r.) hetmanem polnym został jeden z najwierniejszych i dość wpływowych stronników królewskich - Mikołaj H. Sieniawski ${ }^{22}$. Jego śmierć w 1683 roku nie pozwoliła jednak wykorzystać go do szachowania poczynań Jabłonowskiego, dążącego do emancypacji spod wpływów króla. Kolejny hetman polny, który także zaliczał się do głównych stronników Sobieskiego, a w latach 1670-1672 był w zasadzie jego prawą ręką - Andrzej Potocki, nie wykazał się już większą aktywnością polityczną, starając się raczej zachować neutralność w polityce wewnętrznej. Nie ma jednak pewności, czy właściwie odczytujemy postawę Potockiego w tym okresie, mimo że istnieje ważne studium na ten temat, oparte na analizie korespondencji kasztelana krakowskiego ${ }^{23}$. Jeszcze w przededniu kampanii wiedeńskiej, po odbyciu sejmiku przedsejmowego województwa krakowskiego, Potocki pisał do podczaszego wiskiego Stanisława Antoniego Szczuki: „Lubo zaś $\mathrm{z}$ wielkim niewczasem i fatygą $\mathrm{w}$ dzień sam sejmiku zbieżałem, tego nie żałuję, bo $\mathrm{z}$ łaski Bożej szczęśliwie pod dyrekcyją jmp. chorążego koronnego [Hieronima Augustyna Lubomirskiego - Z.H.] ad mentem propozycjej w instrukcjej JKM wyrażonych sejmik stanął"24. Wybrany wówczas skład posłów na sejm w pełni odpowiadał Janowi III, a Potocki stwierdził, że tak pomyślny przebieg sejmiku to rezultat jego bytności w Proszowicach ${ }^{25}$. Widać zatem, że kasztelan krakowski wykonywał ważne zadania dla dworu, takie jak wywarcie wpływu na sejmik województwa „górnego", by jego stanowisko było zgodne z linią polityczną króla. Aby określić, jak sytuacja wyglądała po 1683 roku, gdy władza Jabłonowskiego nad wojskiem systematycznie się zwiększała, mimo przyznania buławy polnej Potockiemu, musimy przeprowadzić kolejne badania.

W latach panowania Jana III jego patronat wojskowy przenikał się wzajemnie z patronatem Jabłonowskiego czy Sieniawskiego. Liczba wpływowych oficerów w wojsku zależnych od króla, a wcześniej od hetmana Sobieskiego z wolna jednak malała, co paradoksalnie nabrało tempa po kampanii wiedeńskiej. Zresztą same działania wojenne 1683 roku miały duży wpływ na zmianę pokoleniową w wojsku, wielu bowiem starych i doświadczonych oficerów nie wytrzymało trudów kampanii i zmarło, jak chociażby sam Sieniawski ${ }^{26}$. Jabłonowski jako główny administra-

22 J. Stolicki, Wobec wolności i króla. Działalność polityczna szlachty ruskiej, ukrainnej i wotyńskiej w latach 1673-1683, Kraków 2007, s. 252.

23 M. Wagner, Andrzej Potocki, hetman polny koronny (1684-1691) [w:] idem, ,, W cieniu szukamy jasności i chwały”. Studia z dziejów panowania Jana III Sobieskiego (1684-1696), Siedlce 2002, s. 4960.

24 A. Potocki do S.A. Szczuki, Jakubowice, 21 XII 1682, Archiwum Główne Akt Dawnych w Warszawie [dalej: AGAD], Archiwum Publiczne Potockich [dalej: APP], sygn. 315, s. 40-41.

${ }_{25}$ Zob. ibidem. Trzech z sześciu wybranych wówczas posłów było zresztą oficerami komputu koronnego - H.A. Lubomirski, oboźny koronny M.Ś. Chełmski oraz starosta kowalski Władysław Morsztyn.

26 Por. M. Wagner, Towarzysze broni..., s. 59-63. Te straty nie pozostawały bez wpływu na kondycję psychiczną niektórych kluczowych dla Sobieskiego wojskowych współpracowników. Andrzej Potocki pisał pod koniec $1683 \mathrm{r} .:$, ,[...] i mnie adaugentur dolores ledwo znośne, kiedy to w jednej roku ćwierci dwóch braci, siostrzeńca i syna grzebię [...]", A. Potocki do S.A. Szczuki, Lwów, 22 XII 1683, AGAD, APP, sygn. 315, s. 51. Potocki wspominał tu przede wszystkim hetmana Sieniawskiego 
tor armii miał większy wpływ na tworzenie nowego zaplecza niż król, przebywał on w końcu przy wojsku, trzymając rękę na pulsie. Król nie pozostawał jednak bez możliwości oddziaływania na wojsko. Istotną rolę w utrzymaniu wpływów w armii przez Sobieskiego za pomocą mechanizmów patronatu powinny odgrywać oddziały rodziny monarchy i tak zwana gwardia komputowa. Jan III w tej materii kierował się rozwiązaniami stosowanymi przez Jana Kazimierza ${ }^{27}$. Pułk królewski Sobieskiego, włącznie z wyodrębnionym po 1685 roku pułkiem królewicza Jakuba, razem z oddziałami komputowej gwardii rodziny królewskiej stanowiły pokaźną część komputu koronnego. W latach 1677-1683, przy 12150 etatach, tego typu jednostki stanowiły jedną czwartą całości, zaś w 1686 roku, przy trzykrotnie większym etacie, pułki jazdy i gwardia komputowa Sobieskich dawały $20 \%$ całości $^{28}$. Był to bardzo duży procent wojska zależnego bezpośrednio od osoby króla i w istotnym stopniu zależnego od jego decyzji, choć jako oddziały komputowe podlegały one władzy hetmanów, czyli w pierwszym rzędzie Jabłonowskiemu. Niewątpliwie kwestia, jak monarcha wykorzystywał oddziały należące do niego i jego rodziny do utrzymywania wpływów w wojsku oraz do prowadzenia swojej polityki, pozostaje nadal niezbadana, a zajęcie się nią stanowi ważny postulat badawczy.

Jeśli chodzi o jednostki noszące imię monarchy, nie możemy pominąć faktu, że za Jana III, po raz pierwszy od 1666 roku, pojawiły się chorągwie JKM (husarska i petyhorska) oraz cały pułk jazdy monarchy w kompucie litewskim. Pozostaje pytanie, jak powstanie tego typu form organizacyjnych wiązało się z kwestią zwalczania wpływów Sapiehów w wojsku litewskim, a także na obszarze całego Wielkiego Księstwa ${ }^{29}$. Wydaje się bowiem, że pułk królewski z rotami husarską i petyhorską miał takie same zadania jak ten pod komendą pisarza litewskiego Aleksandra Hilarego Połubińskiego w dobie Jana Kazimierza ${ }^{30}$, czyli zapewnienie monarsze kontroli nad częścią sił litewskich. Zajęcie się tym problemem jest tym bardziej zasadne, że w latach 1687-1696 dowódcą roty husarskiej JKM i całego pułku królewskiego ${ }^{31}$

(siostrzeńca) oraz dwóch pułkowników wojska koronnego - syna Stanisława, starostę halickiego, oraz kuzyna Dominika, podskarbiego nadwornego.

${ }_{27}$ Podkreślił to ostatnio Mirosław Nagielski; M. Nagielski, Wkład jednostek gwardyjskich monarchy $w$ wysilek militarny Rzeczypospolitej za dwóch ostatnich Wazów (1632-1668) [w:] „W hetmańskim trudzie”. Księga pamiatkowa ku czci Profesora Jana Wimmera, red. Z. Hundert, M. Wagner, Oświęcim 2017, s. 120.

28 Z. Hundert, Komputowe oddziały rodziny królewskiej w kampanii mołdawskiej 1686 roku $w$ świetle rozkazów i sprawozdania sejmowego hetmana wielkiego koronnego Stanisława Jana Jabłonowskiego [w:] Jarzmo Ligi Świętej? Jan III Sobieski i Rzeczpospolita w latach 1684-1696, red. D. Milewski, Warszawa 2017, s. 163-169.

${ }_{29}$ Zob. Komput do pułku Króla Jmści, AGAD, Archiwum Zamoyskich [dalej: AZ], sygn. 3112, s. 587; Z. Hundert, Komputowe oddziały..., s. 169.

30 Dużo uwag na ten temat, także w aspekcie wojskowej klienteli: A.A. Majewski, Aleksander Hilary Polubiński (1626-1679), marszatek wielki litewski. Działalność polityczno-wojskowa, Prace Instytutu Historycznego Uniwersytetu Warszawskiego, Warszawa 2017.

31 Komenda nad królewską chorągwią husarską i królewskim pułkiem jazdy z jednej strony należała do prestiżowych, z drugiej wiązała się z realną władzą w wojsku, lokując ją dość wysoko w strukturze dowódczej, zarówno komputu koronnego, jak i litewskiego. Na dowód warto wskazać dwie sytuacje, gdy w momencie wystąpienia wakansu na stanowisku porucznika husarii JKM i równocześnie całego pułku 
w kompucie litewskim był Hrehory Antoni Ogiński, jeden z najbardziej zagorzałych przeciwników Sapiehów, który podjął z nimi bezpardonową walkę po śmierci Jana III i stał się jednym z przywódców republikantów oraz współautorem pogromu wojsk sapieżyńskich pod Olkiennikami w listopadzie 1700 roku $^{32}$. Wydaje się zatem, że królowi udało się zainstalować własny patronat wojskowy w Wielkim Księstwie Litewskim, który mógł mieć udział w upadku hegemonii Sapiehów na początku XVIII wieku. Pamiętajmy jednak, że Jan III nie zawsze mógł politycznie liczyć na towarzystwo ze swoich litewskich jednostek. W 1694 roku manifest w sprawie poparcia opozycyjnego wobec dworu wojewody wileńskiego i hetmana wielkiego Kazimierza Jana Sapiehy podpisało dwóch towarzyszy chorągwi królewskich - Kazimierz Stenbocki i Kazimierz Malawski ${ }^{33}$. Wielu obserwatorów życia publicznego brało w ówczesnym konflikcie Sapiehy z biskupem wileńskim Konstantym Kazimierzem Brzostowskim (za którym stał dwór) stronę hetmana, upatrując w jego urzędzie przeciwwagę dla królewskich zakusów wzmocnienia władzy. Jak notował ksiądz Tomasz Perkowicz, informator podskarbiny koronnej Anny z Gnińskich Zamoyskiej: „Co zaś do sprawy jmp. wojewody wileńskiego, częste tu są dyskursy, że nie trzeba dopuszczać, aby buławy tak bardzo naginano, bo po tym powagę ich złamią, którą Rzeczpospolita dlatego chowa, aby mogła czym pogrozić majestatom, gdyby się nazbyt wyniosły"34. W wyrobieniu takiego stanowiska opinii publicznej klientela wojskowa Sapiehy - ale i Jabłonowskiego - musiała odgrywać ważną rolę.

W świetle poczynionych w historiografii ustaleń wiemy, że w czasach Sobieskiego osoby związane $\mathrm{z}$ wojskiem były angażowane do działalności politycznej. Brakuje na pewno opracowania tych kwestii w kontekście określonej strategii, tym bardziej na dogłębne zbadanie zasługuje problem sprawowania władzy przez Jana III ze wsparciem środowiska wojskowego. Trzeba też odpowiedzieć na pytanie, jaką

dwóch oficerów bezskutecznie starało się o tę godność. W 1687 r., po śmierci Krzysztofa Białłozora, chorążego litewskiego i dowódcy litewskiej husarii Jana III, o zwolnioną komendę zabiegał kasztelan witebski Michał Kazimierz Kociełł; w 1696 r. zaś, gdy zmarł cześnik koronny i dowódca husarii oraz pułku jazdy JKM Mikołaj Złotnicki, królewskim porucznikiem zapragnął być kasztelan halicki Krzysztof Skarbek. Zarówno jeden, jak i drugi swoich ambicji w tej materii nie zrealizowali; zob. M.K. Kociełł do S.A. Szczuki, Smorgonie, 11 III 1687, AGAD, APP, sygn. 163a, t. 14, s. 1351-1352; K. Skarbek do Jana III, Jabłonna, 8 VI 1696, Нацыянальны гістарычны архіў Беларусі, Мінск, f. 695, vop. 1, sygn. 224, k. 194. Za udostępnienie fotokopii listu K. Skarbka serdecznie dziękuję Janowi Jerzemu Sowie.

A. Rachuba, Hrehory Antoni Ogiński [w:] Poczet hetmanów Rzeczypospolitej. Hetmani litewscy, red. M. Nagielski, wyd. 2 popr. i uzup., Warszawa 2006, s. 236-244. Zob. też duże studium o antysapieżyńskiej działalności Ogińskiego w latach 1697-1698: Д. Віцько, Спроба рэспубліканцаў дамагчыся ўлады над войскам ВКЛ у 1697-1698 г., „Беларускі Гістарычны Агляд” 2008, т. 15, сш. 1-2 (28-29), s. 305-328.

33 Manifest albo raczej spisek wojska W. Ks. Lit. in a. 1694, d. 10 augusta pod Dubienką, AGAD, Archiwum Warszawskie Radziwiłłów, dz. II, ks. 27, s. 225-227.

34 T. Perkowicz do A. Zamoyskiej, Lwów, 31 I 1695, AGAD, AZ, sygn. 1380, s. 87-88. Więcej o konflikcie Sapiehy z Brzostowskim i o roli w tym hetmańskiej klienteli wojskowej zob. M. Sawicki, Konflikt biskupa wileńskiego Konstantego Kazimierza Brzostowskiego z Kazimierzem Janem Sapieha w latach 1693-1696 [w:] Studia z dziejów Wielkiego Księstwa Litewskiego (XVI-XVIII wieku), red. S. Górzyński, M. Nagielski, Warszawa 2014, s. 383-401. 
rolę odgrywał tu system patronatu. Kolejnych badań potrzebuje kwestia potencjalnych profitów, które można było uzyskać w działaniach na rzecz króla czy na rzecz jego politycznych sojuszników. Że współpracownicy Sobieskiego promowali przed królem swoich protegowanych, dowodzi na przykład list klienta Mikołaja H. Sieniawskiego i porucznika jego roty husarskiej - Nikodema Żaboklickiego. Pisał on do swojego patrona w 1676 roku z podziękowaniami za protekcję u króla w sprawie uzyskania urzędu chorążego bracławskiego ${ }^{35}$. Obecnie znamy wiele pojedynczych przypadków z całego panowania Jana III, gdy wojskowi byli beneficjantami nadan, nie wiemy jednak, czy były one elementem przyjętej przez dwór strategii budowania własnego zaplecza w wojsku i na prowincjach ${ }^{36} \mathrm{i}$ jakie też były tego rezultaty. Nierozpoznane pozostają w dalszym ciągu układy wewnętrzne w Rzeczypospolitej, przede wszystkim po 1683 roku, dlatego nie do końca możemy zrozumieć specyfikę koronnego patronatu wojskowego tego okresu, niejasne pozostaje także, które patronaty się wzajemnie przenikały, które ze sobą rywalizowały, a których współpraca i rywalizacja były tylko pozorne. Pytanie też, czy wszystkie zależności powinniśmy rozpatrywać w kontekście wojskowych patronatów. Konfederacja wojskowa Piotra Bogusława Baranowskiego z lat 1696-1697 dowodzi przecież, że istniały w wojsku środowiska, które potrafiły promować ogólny interes żołnierzy w oderwaniu od wpływowych magnatów, którzy za pomocą swojego patronatu długo nie umieli zdobyć wpływu na kierownictwo konfederacji i podporządkowanych mu żołnierzy ${ }^{37}$. Świetnie obrazuje to uwaga ks. Perkowicza, który pisał: „wiemy, iż większa część wojska samych tylko zasług szuka, a fakcji żadnych cierpieć nie chce, ani będzie, gdy się im jawnie odkryją"38. Wojsko koronne jednak, zwłaszcza w latach 90., uległo istnej „prywatyzacji”, magnaccy oficerowie bowiem wykorzystywali swoje oddziały do pilnowania własnych majętności, a nie do realizowania strategicznych planów dowództwa wojsk koronnych ${ }^{39}$.

Niewątpliwie zagadnienie patronatu wojskowego i wojskowej klienteli w czasach Sobieskiego wciąż stanowi wyzwanie dla historyków. Nadal istnieje zapotrzebowanie na badania nad wykorzystywaniem klienteli wojskowej do wpływania na przebieg obrad sejmowych (wojskowi jako posłowie cywilni czy poselstwa wojskowe),

35 Zob. N. Żaboklicki do M.H. Sieniawskiego, Zaleszany, 2 IV 1676, Biblioteka XX. Czartoryskich w Krakowie, rkps 5992, f. 49168; Z. Hundert, J.J. S ow a, Od towarzysza jazdy do wojewody podolskiego. Przebieg stużby wojskowej Nikodema Żaboklickiego w latach 1656-1706, „Res Historica” 2016, nr 42, s. 143.

36 Zob. J. Stolicki, Rozdawnictwo wakansów przez Jana III jako metoda tworzenia partii dworskiej [w:] Faworyci i opozycjoniści. Król a elity polityczne w Rzeczypospolitej XV-XVII wieku, red. R. Skowron, M. Markiewicz, Kraków 2006, s. 374.

37 J.J. Sowa, Zawiazanie konfederacji Baranowskiego a postuszeństwo oficerom i dyscyplina wojskowa [w:] Przysięga wojskowa. Idea i praktyka. Z dziejów wojskowości polskiej i powszechnej, red. A. Niewiński, Homo Militans, t. 4, Oświęcim 2016, s. 80-87.

38 T. Perkowicz do A. Zamoyskiej, Lwów, 13 II 1697, AGAD, AZ, sygn. 1380, s. 235.

39 Zob. J.J. Sow a, Jednostki komputowe Adama Mikołaja Sieniawskiego do 1702 roku, cz. 1: Udziat w dziataniach wojennych do 1696 roku [w:] Studia nad staropolska sztukq..., t. IV, s. 221; cz. 2 [w:] Studia nad staropolska sztuka..., t. V, red. Z. Hundert, K. Żojdź, J.J. Sow a, Oświęcim 2017, s. $262-$ 263. 
zwłaszcza w dobie panowania Jana III, czy innych systemowych instytucji: sejmików, trybunałów, komisji etc. Duże znaczenie, szczególnie w czasach, gdy buławę wielką trzymał Jabłonowski, mają tu badania nad tym, jaką rolę odgrywała klientela wojskowa w przyznawaniu środków $\mathrm{z}$ funduszu hibernowego oraz jak sam fundusz hibernowy służył w procesie budowy patronatu wojskowego ${ }^{40}$. Mimo wysunięcia tylu postulatów badawczych cieszy przede wszystkim to, że coraz częściej prowadzone są badania cząstkowe, które pozwalają odkrywać kolejne fakty i pomagają zrozumieć funkcjonowanie pozasystemowych mechanizmów sprawowania władzy, takich jak patronat wojskowy, które miały ogromny wpływ na pracę ustrojowych instytucji państwa, a które przez wiele dziesięcioleci nie były przez historyków zauważane.

\section{BIBLIOGRAFIA}

\section{Źródła rękopiśmienne}

Archiwum Główne Akt Dawnych w Warszawie:

Archiwum Publiczne Potockich, sygn. 163a (t. 14), 315.

Archiwum Warszawskie Radziwiłłów, dz. II, ks. 27.

Archiwum Zamoyskich, sygn. 1380, 3112.

Biblioteka XX. Czartoryskich w Krakowie, rkps 5992.

Нацыянальны гістарычны архіў Беларусі, Мінск, f. 695, vop. 1, sygn. 224.

\section{Źródła drukowane}

Dupont F., Pamiętniki historyi życia i czynów Jana III Sobieskiego, thum. B. Spieralska, oprac. D. Milewski, Warszawa 2011.

Pisma do wieku i spraw Jana Sobieskiego, oprac. F. Kluczycki, t. 1, cz. 2, Kraków 1881.

\section{Opracowania}

Augustyniak U., W stużbie hetmana i Rzeczypospolitej. Klientela wojskowa Krzysztofa Radziwitla (1585-1640), Warszawa 2004.

Hundert Z., Działalność wojskowa i polityczna Hieronima Augustyna Lubomirskiego w latach 1669-1673 - glosa do biografii [w:] Hortus bellicus. Studia z dziejów wojskowości nowożytnej. Prace ofiarowane profesorowi Mirosławowi Nagielskiemu, red. K. Bobiatyński [et al.], Biblioteka Epoki Nowożytnej, t. 5, Warszawa 2017.

40 Idem, Nervus belli czy finansowe jarzmo Ligi Świętej? Skarb hibernowy a finansowanie wysitku wojennego Korony 1685-1700 [w:] Jarzmo Ligi Świętej..., s. 137-159. 
Hundert Z., Komputowe oddziały rodziny królewskiej w kampanii mołdawskiej 1686 roku $w$ świetle rozkazów i sprawozdania sejmowego hetmana wielkiego koronnego Stanisława Jana Jabłonowskiego [w:] Jarzmo Ligi Świętej? Jan III Sobieski i Rzeczpospolita w latach 1684-1696, red. D. Milew ski, Warszawa 2017, s. 161-186.

Hundert Z., Między buława a tronem. Wojsko koronne $w$ walce stronnictwa malkontentów z ugrupowaniem dworskim w latach 1669-1673, Oświęcim 2014.

Hundert Z., Powiatowe choragwie kozackie (pancerne) województw poznańskiego i kaliskiego w latach 1671-1673 [w:] Do szarży marsz, marsz... Studia z dziejów kawalerii, red. A. Smoliński, t. 6, Toruń 2015, s. 63-106.

Hundert Z., Pozycja Jana III w wojsku koronnym w latach 1674-1683. Utrzymanie czy też utrata wpływów wypracowanych w czasie sprawowania godności hetmańskiej? [w:] Król Jan III Sobieski i Rzeczpospolita w latach 1674-1683, red. D. Milewski, Warszawa 2016, s. 121-151.

Hundert Z., Władysławów Denhoffów dwóch, „Przegląd Historyczny” 2016, t. 107, z. 2, s. $303-310$.

Hundert Z., Wojsko koronne a elekcja 1674 roku [w:] Wokół wolnych elekcji w państwie polsko-litewskim XVI-XVIII wieku. O znaczeniu idei wyboru - między prawami a obowiązami, red. M. Markiewicz, D. Rolnik, F. Wolański, Katowice 2016, s. 308-332.

Hundert Z., Zaciężne wojsko powiatowe sejmiku wiszeńskiego województwa ruskiego w latach 1671-1673 oraz jego rola $w$ działaniach wojskowych i politycznych Jana Sobieskiego, „Przegląd Historyczny” 2017, t. 108, z. 4, s. 641-671.

Hundert Z., Sowa J.J., Od towarzysza jazdy do wojewody podolskiego. Przebieg stużby wojskowej Nikodema Żaboklickiego w latach 1656-1706, „Res Historica” 2016, nr 42, s. $127-181$.

Kamieński A., Skoraszewski Władysław [w:] Polski słownik biograficzny, t. XXXVIII, Warszawa-Kraków 1997, s. 256-259.

Majewski A.A., Aleksander Hilary Polubiński (1626-1679), marszałek wielki litewski. Działalność polityczno-wojskowa, Prace Instytutu Historycznego Uniwersytetu Warszawskiego, Warszawa 2017.

Matwijow ski K., Pierwsze sejmy z czasów Jana III Sobieskiego, Wrocław 1976.

The Military Revolution Debate: Readings on the Military Transformation of Early Modern Europe, ed. C.J. Rogers, Boulder 1995.

Nagielski M., Wkład jednostek gwardyjskich monarchy w wysitek militarny Rzeczypospolitej za dwóch ostatnich Wazów (1632-1668) [w:] „,W hetmańskim trudzie”. Księga pamiatkowa ku czci Profesora Jana Wimmera, red. Z. Hundert, M. Wagner, Oświęcim 2017, s. 97-120.

Rachuba A., Hrehory Antoni Ogiński [w:] Poczet hetmanów Rzeczypospolitej. Hetmani litewscy, red. M. Nagielski, wyd. 2 popr. i uzup., Warszawa 2006, s. 236-244.

Sawicki M., Konflikt biskupa wileńskiego Konstantego Kazimierza Brzostowskiego z Kazimierzem Janem Sapiehą w latach 1693-1696 [w:] Studia z dziejów Wielkiego Księstwa Litewskiego (XVI-XVIII wieku), red. S. Górzyński, M. Nagielski, Warszawa 2014, s. 383-401.

Sokalski M., Między królewskim majestatem a szlachecka wolnością. Postawy polityczne szlachty małopolskiej w czasach Michała Korybuta Wiśniowieckiego, Kraków 2002.

Sow a J.J., Jednostki komputowe Adama Mikołaja Sieniawskiego do 1702 roku, cz. 1: Udziat $w$ działaniach wojennych do 1696 roku [w:] Studia nad staropolska sztuka wojenna, t. IV, red. Z. Hundert, K. Żoj dź, J.J. Sowa, Oświęcim 2015, s. 209-221. 
Sow a J.J., Jednostki komputowe Adama Mikołaja Sieniawskiego do 1702 r., cz. 2 [w:] Studia nad staropolska sztuka wojenną, t. V, red. Z. Hundert, K. Żojdź, J.J. Sowa, Oświęcim 2017, s. 247-264.

Sow a J.J., Nervus belli czy finansowe jarzmo Ligi Świętej? Skarb hibernowy a finansowanie wysiłku wojennego Korony 1685-1700 [w:] Jarzmo Ligi Świętej? Jan III Sobieski i Rzeczpospolita w latach 1684-1696, red. D. Milewski, Warszawa 2017, s. 137-159.

Sowa J.J., Zawiazanie konfederacji Baranowskiego a postuszeństwo oficerom i dyscyplina wojskowa [w:] Przysięga wojskowa. Idea i praktyka. Z dziejów wojskowości polskiej i powszechnej, red. A. Niewiński, Homo Militans, t. 4, Oświęcim 2016, s. 80-87.

Stolicki J., Rozdawnictwo wakansów przez Jana III jako metoda tworzenia partii dworskiej [w:] Faworyci i opozycjoniści. Król a elity polityczne w Rzeczypospolitej XV-XVII wieku, red. R. Skowron, M. Markiewicz, Kraków 2006, s. 359-375.

Stolicki J., Wobec wolności i króla. Działalność polityczna szlachty ruskiej, ukrainnej i wotyńskiej w latach 1673-1683, Kraków 2007.

Wagner M, Andrzej Potocki, hetman polny koronny (1684-1691) [w:] idem, ,W Wieniu szukamy jasności i chwały”. Studia z dziejów panowania Jana III Sobieskiego (1684-1696), Siedlce 2002, s. 49-60.

Wagner M., Stanisław Jabłonowski (1634-1702). Polityk i dowódca, t. 1, Siedlce 1997.

Wagner M., Towarzysze broni Jana Sobieskiego [w:] Jan Sobieski - wódz i polityk (16291696). W trzechsetna rocznice śmierci, red. J. Wojtasik, Prace Instytutu Historii Wyższej Szkoły Rolniczo-Pedagogicznej w Siedlcach, nr 23, Siedlce 1997, s. 55-63.

Wiśniewski K., Jan Sobieski jako marszatek wielki koronny [w:] Marszałek $i$ hetman koronny Jan Sobieski, red. D. Milew ski, Warszawa 2014, s. 19-36.

Żojdź K., Klientela hetmana wielkiego litewskiego Jana Karola Chodkiewicza i jej losy po śmierci patrona, „Przegląd Historyczny” 2015, t. 106, z. 1, s. 31-68.

Żojdź K., Patronat wojskowy i klientela hetmańska Jana Karola Chodkiewicza. Zarys problematyki [w:] Studia nad staropolska sztuka wojenna, t. IV, red. Z. Hundert, K. Żojdź, J.J. Sowa, Oświęcim 2015, s. 69-92.

Żojdź K., „Stronnictwo Zygmunta III Wazy w Wielkim Księstwie Litewskim w latach 1603-1621”, mps pracy doktorskiej napisanej w Instytucie Historycznym Uniwersytetu Warszawskiego pod kierunkiem prof. dra hab. M. Nagielskiego, Warszawa 2018.

Віцько Д., Спроба рэспубліканцай дамагчыся ўлады над войскам ВКЛ у 1697-1698 г., „Беларускі Гістарычны Агляд” 2008, т. 15, сш. 1-2 (28-29), s. 305-328. 